\title{
Ancient HTLV-I provirus DNA in Andean mummies
}

\author{
Hong-Chuan Li ${ }^{1}$, Toshinobu Fujiyoshi ${ }^{1}$, Hong Lou ${ }^{1}$, Shinj Yashimi $^{1}$, Shunro Sonoda ${ }^{1}$, Luis Cartier ${ }^{2}$, \\ LaUtaro NúNẼzZ ${ }^{3}$, Iván Muñoz ${ }^{4}$, Satoshi Horai ${ }^{5}$, Kazuo TaJima ${ }^{6}$
}

\section{RESUMEN}

El virus humano de las leucemias T tipo 1 (HTLVI) es prevalente en todo el mundo tanto en la población indígena de Sudamérica, como Asia (Japón), la cuenca del Caribe, y el centro-este de Africa. Existen dos linajes mayores de HTLV-I: uno asiático, mongoloide y otro africano, negroide.

Con el propósito de investigar el origen del HTLV-I prevalente entre los andinos se buscó aislar el provirus HTLV-I del ADN de los restos de médula ósea preservados en cuerpos humanos, de culturas preincaicas, conservados en el museo arqueológico «R.P. G. Le Paige», Universidad Católica del Norte, de San Pedro de Atacama. Luego fue comparado con el provirus de HTLV-I encontrado en los actuales habitantes de la zona, que fue obtenida de los linfocitos circulantes y también con el provirus de los japoneses.

La secuencia nucleotídica de los clones de ADN revela que el ADN antiguo de los cuerpos prehispánicos muestra los 159 bp de px del HTLV-I y 2os 110 bp de la Beta-globulina y los 267 bp del HLA DQB 1-0502, mostrando muy pequeñas variaciones al compararlo con la secuencia del ADN contemporáneo aislado de japoneses y chilenos portadores de HTLV-I.

1 Department of Virology, Faculty of Medicine, Kagoshima University, Sakuragaoka 8-35-1, Kagoshima 890-8520, Japan.

2 Department of Clinical Neurology, Chile University, Santiago, Chile.

3 Institute of Archaeology, Research and Museum North Catholic University, San Pedro de Atacama, Chile.

4 Department of Archaeology, Tarapaca University. Arica, Chile.

5 Department of Biosystems Sciences, The Graduate University for Advanced Studies, Hayamacho, Miura-gun 240-0193, Japan.

6 Division of Epidemiology, Aichi Cancer Center Research Institute, Kanokoden, Chikusa-Ku, Nagoya 464-8681, Japan.
Estos resultados sugieren que los ancestros de los habitantes prehispánicos de los andes pudieron haber emigrado desde el continente asiático, para instalarse en el norte de Chile y que fueron infectados con HTLV-I hace más de 1.000 años.

\section{Introduction}

Human T-cell leukemia virus type I (HTLV-I) is the causative agent for the adult T-cell leukemia (ATL) and HTLV-I-associated myelopathy/tropical spastic paraparesis (HAM/TSP) which are geographically clustered with HTLV-I carrier populations in the Southwest of Japan and Central-South America (Mongoloids), in tropical Africa and the Caribbean basin as well as the Atlantic coast in South America (Negroids), in Papua New Guinea (Melanesian) and in the North-East of Australia (Australoid). The geographic and ethnic clusters of HTLV-I carriers and patients in the world may be explained by the natural history of HTLV-I infection whose transmission routes are limited to mother to-child (breast feeding) and man-to-woman (sexual contact).

Anthropologists infer that aboriginal Americans migrated from the Asian Continent in several waves via Beringia around 21,000 to 14,000 years ago, and diverged to form the ancestors of natives of the Andes and other parts of South America. This anthropological postulate is attested to the limited nucleotide diversity of mitochondrial DNA within and between contemporary native Americans.

We speculate that Andes natives carring HTLV-I might share common Asian ancestors with contemporary HTLV-I carriers in Southwestern Japan, and indeed demonstrated genetic similarity in HLA DRB 1-DQB 1 haplotypes between Southern Japanese and Andes natives.

In order to ascertain whether ancient people in the Andes were genetically related to Asian Mongoloids and infected with HTLV-I of this origin, we investigated DNA sequences of the HTLV-I pX gene and other human specific genes (HLA-DQB 1 
and (globin genes) isolated from bone marrow DNA of mummies from the Chilean desert of San Pedro de Atacama as recently documented.

\section{Material and Methods}

Two sites in northern Chile were selected for the present field of study (Fig 1). Approximately $30 \mathrm{ml}$ of blood samples were collected from contemporary native Chileans and Japanese with informed consent. The Archaeological Museum of San Miguel (MASM) around Azapa valley and the Museo Padre le Paige (MPP) in Atacama desert preserved human bodies excavated from cemeteries and some bodies were examined for dated by carbon 14 (C 14). Paired samples of bone parts and bone marrow were collected from each of 119 bodies (77 in MASM and 42 in MPP). Femurs and humeri were prepared for wedged bone cuts $(1 \times 2 \mathrm{~cm})$ and bone marrow (1-2 grams) by cleaning the skin with alcohol, making a $2 \times 2 \mathrm{~cm}$ hole beneath the greater tubercle of the femur with disposable bone cutters and scraping the bone marrow powder with disposable spatulas.
Each specimen of bone and bone marrow was individually wrapped in a plastic bag under desiccating conditions. AU procedures were conducted in an isolated dust-free room by two of the authors (K.T. and S.S.) who used disposable clothes and gloves, together with fine-filter masks, to prevent contamination of samples with the sampler's body materials.

\section{Extraction of DNA:}

Isolation of DNA was carried out according to Pääbo $\mathrm{S}$ and Poinar HN et al.(7,8) using a Geneclean Kit for Ancient DNA (Bio101, INC. La Jolla CA). The final yields of purified mummy DNA ranged from 0.5 to $1.0 \mathrm{~g}$. One hundred to $500 \mathrm{mg}$ of bone marrow samples were placed in a Eppendorf tube, mixed with $850 \mu 1$ of DNA dehybernation solution A and 150111 DNA dehybernation solution A2 and homogenated with a $1.5 \mathrm{~m} 1$ tube mixer (IEDA No. 9992, IEDA Co. Tokyo) on a separate clean bench.

The homogenates were incubated with $20 \mu .1$ of
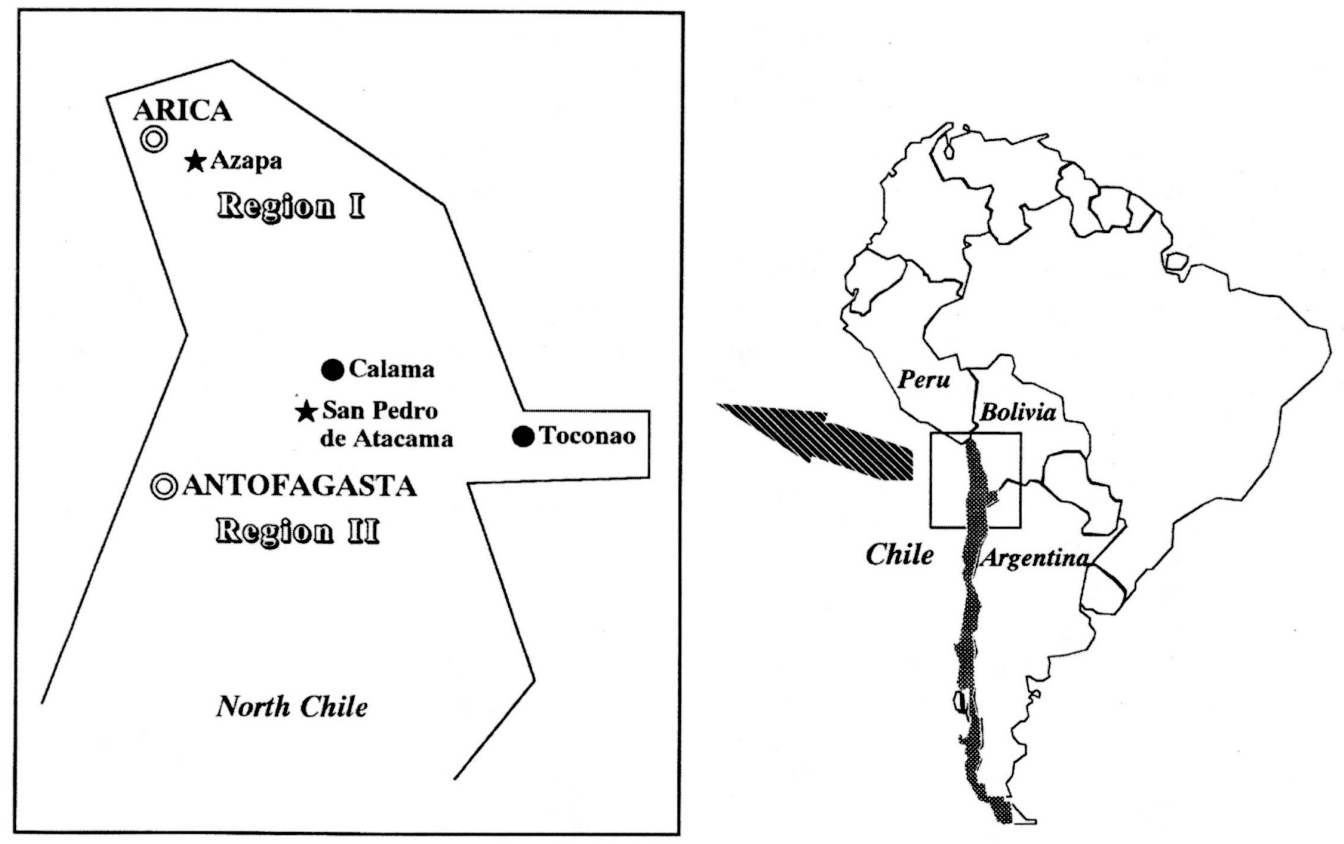

Figure 1. Map of North Chile (Ist and IInd Regions) showing locations in Table 1. • Villagename, *: Site of mummy museum, (O) Regional capital. 
proteinase $\mathrm{K}$ solution $(20 \mathrm{mg} / \mathrm{ml})$ at $55{ }^{\circ} \mathrm{C}$ overnight with agitation and centrifuged at $14,000 \mathrm{rpm}$ for 5 min to pellet particulate material. The supernatant fluid was transferred to a Spin Filter tube and was added $300 \mu \mathrm{l}$ of Ancient DNA Glassmilk suspension followed by incubation at room temperature for 30 minutes. The mixture was centrifuged at 14,000 rpm for one minute to collect Glassmill/DNA complexes, while were then resuspended in $0.5 \mathrm{ml}$ Salton Wash 1 , gently vortexed to make an even suspension, and centrifuged at 14,000 rpm for 2 minutes to pass liquid to catch tubes. Washing was repeated with Salton Wash 2, then with $0.5 \mathrm{ml}$ Ancient Alcohol Wash, repeated twice.The cleaned Glassmilk/DNA complex was added to $100 \mu \mathrm{l}$ of Elution solution, suspended with a hand vortex and centrifuged at 14,000 rpm for one minute to elute DNA for PCR amplification. The eluted DNA was ready to be subjected to PCR amplification. An extraction control was set up to follow all procedures without addition of mummy bone marrow.

\section{PCR Amplification and Cloning:}

The eluted DNA was subjected to PCR amplification of HTLV-I pX, human Bglobin and HLA-DQB 1 genes using paired sets of primers for the first and second PCR according to the standard protocol. We used a GeneAmp PCR system 2400 (Perkin-Elmer, Norwalk, CT, USA) to amplify $5 \mu \mathrm{l}$ aliquots of eluted DNA samples in a $50 \mu 1$ reaction mixture (10 $\mathrm{mM}$ Tris-HC1 (pH 8.3), $50 \mathrm{mM} \mathrm{KCI}, 1.5 \mathrm{mM} \mathrm{MgC}$ 12, $1.25 \mathrm{mM}$ of each dNTP, 20 pico-mol of each primer, $2.5 \mathrm{U}$ of AmpliTaq GoldTM polymerase (Roche Molecular System, Inc., New Jersey, USA)). PCR amplification was carried out under the following conditions: activation of the polymerase at $95^{\circ} \mathrm{C}$ for $9 \mathrm{~mm}$., 40 cycles of denaturation at $94^{\circ} \mathrm{C}$ for $30 \mathrm{sec}$., annealing at $58^{\circ} \mathrm{C}$ for $60 \mathrm{sec}$., and a final extension at $60^{\circ} \mathrm{C}$ for $10 \mathrm{~mm}$. The first and second sets of primers for HTLV-I pX were SN543/ SN544 and SK43/SK44 (9); for human P-globin they were KM29/KM38 and PC03/PC04 (10); and for HLA-DQB1 they were DQ 15/DQBS7T and DQ267 $(11,12)$ which were also used for the second amplification of HLA-DQB 1. The amplified DNA were electrophoresed on $1.5 \%$ agarose gels to detect specitic DNA bands. One $\mu$ l aliquotes of PCR products were rendered for DNA cloning using an Original TA Cloningt Kit (Invitrogen Co. CA) as described by Goldstein JL and Smith LM et al. $(13,14)$. More than thirty clones were selected using blue/white color screening on indicator plates and the recombinant DNA in plasmids was isolated from the positive colonies.

In parallel with mummy DNA amplification, 6 DNA samples from contemporary Chilean and Japanese HTLV-I carriers were similarly amplified for HTLV-I pX, human P-globin and HLA-DQB 1 genes using another clean bench in a separate room. Laboratory contamination was monitored by parallel setting of extraction (no bone marrow sample included) and PCR (no DNA extract included) controls.

\section{DNA Sequencing}

The cloned DNA was identified by size, excised by Apa I and EcoR I, and rendered for DNA sequencing with a Hitachi SQ-5500 automated sequencer (Hitachi Co., Tokyo) according to the manufactur's instructions. 159 bases of the HTLV-I pX region, 110 bases of $\beta$-globin and 267 bases of HLA-DQB 1 were sequenced with reference to the known sequences of HTLV-I pX (ATK-1), (3-globin and HLA-DQBI).

\section{Morphological Examination of human Bone Marrow Samples and Quantitation of DNA:}

The human bone marrow samples were subjected to morphological examination under a scanning electron-microscope to investigate cellular components preserved in the mummy bone marrow. For quantitation, extracted DNA from bone marrow samples was diluted 1:2. 1:4, 1:8, 1:16, 1:32, 1:64 and 1:128 with commercially purchased filter-sterilized water (Nacalai Tesque, Inc., Kyoto, Japan). Five (1 aliquots of the diluted DNA were examined for HTLV-I pX DNA sequencing as described above. The PCR-positive products were cloned for confirmation.

\section{Results}

Antibodies to HTLV-I in sera were screened by PA testing and confirmed by ELISA, IF and WB tests (HTLV-I Western blot) as described earlier(S). Serological tests for anti-HTLV-I showed that all 157 Aimara people in Parinacota, Caquena, Visiviri and Putre, together with 86 Atacama people in Calama and Socaire, were negative for antiHTLV-I. On the other hand, $12.3 \%$ (9/73) of Atacama people in Toconao and San Pedro de Atacama were positive. 
The HTLV-I seropositivity was as high in some Atacama groups as in HTLV-I endemic groups in Southwestern Japan. All cases showed positive reactions for HTLV-I gag and envelope antigens on HTLV-I WB (Table 1), so all cases were confirmed to be HTLV-J seropositive according to WHO criteria.

A total of 104 cases of bone marrow and 5 samples of contemporary Chilean and Japanese I-1TLV-I carriers' peripheral blood lymphocyte DNA rendered for PCR amplification with pairs of primers for HTLV-I $\mathrm{pX}, \beta$-globin and HLA-DQB 1 genes. One sample from San Pedro de Atacama (SP2) produced a band of 159 base pair(bp) length corresponding to the PCR product of the HTLV-I PX gene. Amplification of $\beta$-globin genes in samples of that two samples from San Pedro de Atacama (SP-2 and SP-11) yielded DNA bands of 110 bp length, is corresponding to the known sequence of the human -globin gene. On amplification of the HLA-DQB 1 gene one sample (T 602) from the Azapa valley produced a positive band of $267 \mathrm{bp}$ length, corresponding to the DNA size constructed by PCR primers (Fig 2).

The nucleotide sequence of the HTLV-I pX region of HTLV-I DNA isolated from human bone marrow is shown in comparison with HTLV-I proviral DNA sequences of contemporary Chilean and Japanese HTLV-I carriers in Fig 3. Three clones of one Chilean HTLV-J carrier's DNA (CHI430)

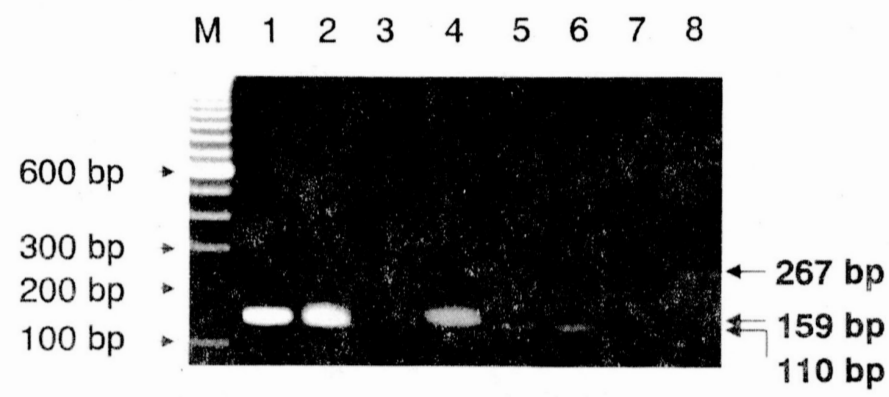

Figure 2. Summary of PCR amplification of HTLV-I pX, human 3-globin and HLA-DQB1 genes from mummy bone marrow DNAs. Lane M; Molecular Markers (100 bp DNA Ladder, Life Technologies, Inc. Gaithersburg, USA), lane 1; HTLV-I pX of Kagoshima HTLV-I carrier peripheral blood lymphocytes (PBL), lane 2; HTLV-I pX of Chile HTLV1 carrier PBL, lane 3; HTLV-I pX of Kagoshima control PBL, lane 4; HTLV-I pX of SP-2 mummy bone marrow DNA (159 bp), lane 5; (globin of SP-2 mummy bone marrow DNA, lane 6; 3-globin of SP-11 mummy bone marrow DNA (110 bp), lane 7; DNA negative control, lane 8; HLA-DQB1 of T-602 mummy bone marrow DNA (267 bp).

HTLV-I

\begin{tabular}{clllll}
\hline $\begin{array}{l}\text { HTLV-I } \\
\text { carriers }\end{array}$ & $\begin{array}{l}\text { Age } \\
* \text { Sex }\end{array}$ & Locality & $\begin{array}{l}\text { PA** } \\
\text { Titer }\end{array}$ & $\begin{array}{l}\text { ELISA*** } \\
\text { (OD. })\end{array}$ & IF**** \\
\hline 1 & $54 \mathrm{~F}$ & Toconao & $\times 128$ & 0.124 & $<\mathrm{xlO}$ \\
2 & $49 \mathrm{~F}$ & Toconao & $\times 512$ & 2.747 & $\times 40$ \\
3 & $59 \mathrm{~F}$ & Toconao & $\times 2048$ & $>3.000$ & $\times 80$ \\
4 & $67 \mathrm{M}$ & Toconao & $\times 64$ & $>3.000$ & $\times 80$ \\
5 & $89 \mathrm{M}$ & S.P.A & $\times 1024$ & $>3.000$ & $\mathrm{x} 80$ \\
6 & $68 \mathrm{~F}$ & S.P.A & $\times 16384$ & $>3.000$ & $\mathrm{x} 80$ \\
7 & $43 \mathrm{~F}$ & S.P.A & $\times 512$ & 2.248 & $\times 20$ \\
8 & $36 \mathrm{~F}$ & S.P.A & $\times 1024$ & $>3.000$ & $\times 80$ \\
9 & $71 \mathrm{~F}$ & S.P.A & $\times 256$ & 0.955 & $<\times 10$ \\
\hline
\end{tabular}

\footnotetext{
*: Confirmed by HTLV-I Western Blot (HTLV-I blot 2.4; Diagnostic Biotechnology, Singapore)

**PA: Particle agglutination (Fujirebio, Tokyo)

$* * *$ ELISA: Eitest ATL, cut off point $=0.123$ (Eizai, Tokyo)

$* * * *$ IF. Immunofluorescence test with MT-1 cells
}

Table 1. Antibody profiles of contemporary HTLV-I carriers in Toconas and San Pedro de Atacama (S.P.A), North Chile 
and one Japanese HTLV-I carrier's DNA (KAG 130) from the contemporary population exhibited the same sequence as the standard ATK-1 clone 159 bp of the HTLV-I pX gene, while 3 clones of another Chilean HTLV-I carrier's DNA(CH1383) showed one point mutation $(\mathrm{C}->\mathrm{T})$ at the 7378 base position. In the first experiment with mummy DNA, seven clones of SP-2 mummy HTLV-I pX DNA showed two point mutations $(\mathrm{A}->\mathrm{G}, \mathrm{T}->\mathrm{C})$ at 7372 and 7473 base positions as compared with a standard HTLV-I clone (ATK-1). In the second experiment using a sample collected from another part of SP-2, we detected 5 random substitutions in the HTLV-I pX sequence at $7358(\mathrm{G}->\mathrm{A}), 7378(\mathrm{C}->\mathrm{T}), 7418(\mathrm{C}->\mathrm{T}), 71$ '14 $(\mathrm{T}->\mathrm{C})$ and $7464(\mathrm{G}->\mathrm{A})$ base positions, although 8 out of 15 clones showed the same sequence as the original ATK-1. Six clones of O-globin positive DNA, amplified from mummy samples SP-2 and SP11, exhibited the same $110 \mathrm{bp}$ sequence of a - globin as in DNA from peripheral blood lymphocytes of contemporary Chileans and Japanese. Nine clones of HLA-DQB 1 positive DNA from the T-602 sample (from the Azapa valley) were sequenced in comparison with the known HLA-DQB $1 * 0502$ sequence. The HLA-DQB 1 sequence of T-602 was the same as that of HLA-DQB ${ }^{* *} 0502$ except for one nucleotide at position 260 (Fig. 4).

The amount of DNA extracted from the human bone marrow (SP-2) was titrated HTLV-I pX DNA molecules for limiting dilution with DNA samples extracted from the contemporary Chilean HTLV-I carrier lymphocytes. Our titration method for HTLV-I pX DNA could exclude all the contaminating DNA of non-human origin such as DNA from soil bacteria, fungi and other animals. Examination under the scannin electron microscope showed the cellular components in the human bone marrow to be cellullar.

\section{Discussion}

The origin of HTLV-I in the Andes population is not completely clear but it is probably linked to the intercontinent dispersal of mongoloids from Asia to South America.

Ethnoepidemiological studies of HTLV-I carriers in South America revealed that Andes natives are closely related to the Japanese population with respect to HLA DRB 1-DQB 1 haplotypes. Recent studies of the phylogeny of HTLV-I using genetic variation of the long terminal repeat (LTR) have allowed HTLV-I to be classified into three major lineages; Melanesian, Central African and Cosmopolitan, the latter being further divided into four subgroups: Transcontinental, Japanese, West African and North African. The HTLV-I of contemporary Andes natives from northern Chile was classified as the transcontinental subtype which is found in southern Japanese and Ainu. In order to confirm the origin of HTLV-I prevailing among Andes natives, we investigated human bone marrow looking for ancient HTLV-I proviral DNA and contemporary DNA from North Chilean people.

Our first success in isolating biologically informative DNA was with 3 human prehispanic bone marrow samples, SP-2, SP-11 and T-602, which showed positive PCR amplification for either HTLV-I provirus DNA on the nuclear DNA of human B-globin and HLA-DQB 1.

Nucleotide sequence analysis of the bone marrow DNA revealed that there was very little variation in sequences of HTLV-I pX in both mummy DNA and contemporary DNA samples, the observed mutation rate of $1.3 \%(2 / 159)$ being the same in ATL patients, although there is a great deal of sequence variation in the $\mathrm{pX}$ region between HTLVr (ATK1) and HTLV-II (x89270).

We found 5 random substitutions in samples from different parts of SP-2 bone marrow in the second experiment, that were likely misincorporated by DNA polymerase during PCR amplification, probably compounded by damage in the SP-2 template DNA. Nuclear DNA (B-globin and HLADQB 1) and HTLV-I pX integrated into the human host genome should be very stable, and would be expected to allow the intercontinental movement of the Paleo-Mongoloids to the Andes region to be examined. The HLA-DQB 1 sequence from sample T-602 was closely related with HLADQB $1 * 0502$ which is prevalent among Japanese and other Asians. Furthermore, it has been reported that HLA-DQB 1 *0502 is strongly linked with HLA-DRB $1 * 1401$ which is frequently found among Southwestern Japanese.

The electron microscopic examination revealed that the human bone marrow samples contained cellular components, including nuclei and membranous constituents providing morphological evidence to substantiate our results for DNA isolation and nuclear genes of $\beta$-globin, HLA-DQB 1 and HTLV-I pX.

Taken together the results, it supports the speculation that the HTLV-I positive was a postTiwanaku individual living in San Pedro de 


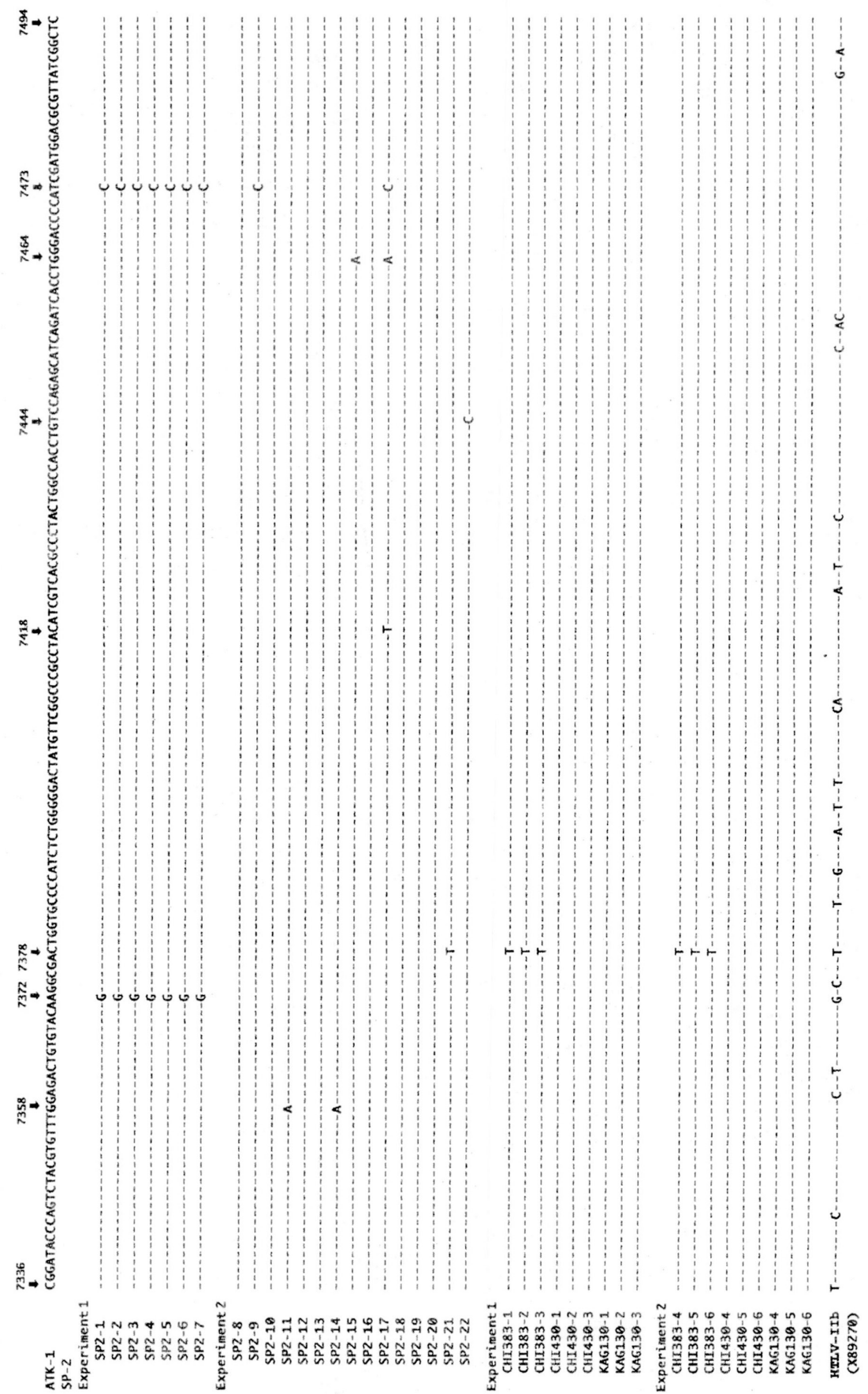

Figure 3. Nucleotide sequences of the pX region of HTLV-I proviral DNA isolated from mummy bone marrow and peripheral blood lymphocytes from Chilean and Japanese HTLV-I carriers. In the first experiment, nucleotide positions 7336-7494 were aligned to show the base constitution of HTLV-I pX clones of SP-2, Chilean HTLV-I carriers (CHI383 and 430), and a Japanese HTLV-I carrier (KAG 130). ATK-1 and X897270 are the standard pX sequences of HTLV-I and HTLV-II, respectively. In the second experiment using another bone marrow collected from a different bone of SP-2, eight out of 15 clones showed the same sequences as the original ATK-1 in the $159 \mathrm{bp}$ of HTLV-I pX genes and the other 7 clones showed little variation. 

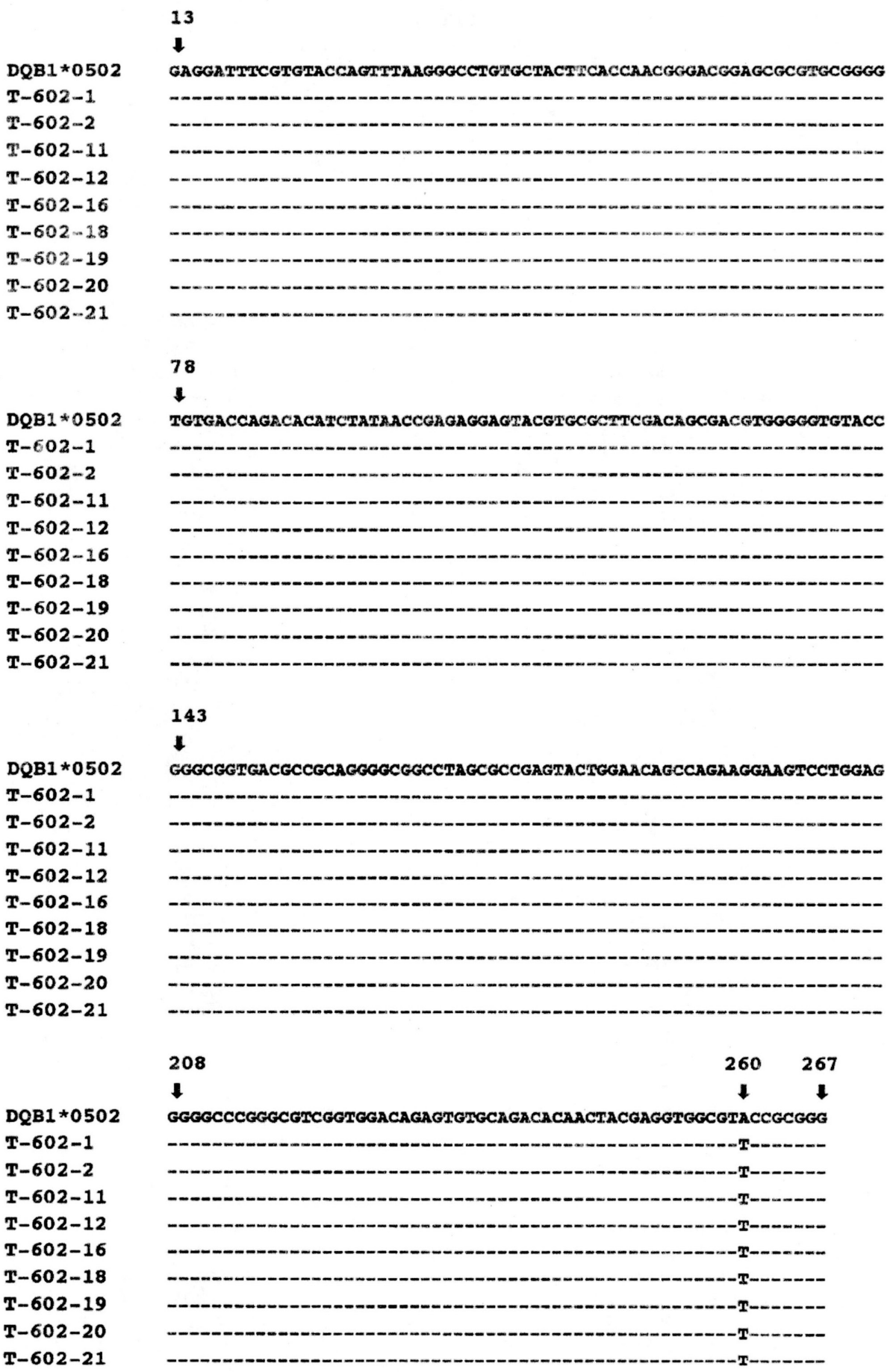

Figure 4. Nucleotide sequences of the HLA-DQB I gene in T-602 clones. Nucleotide positions 13-267 of the HLA-DQB 1 gene were aligned to show a base substitution at position of 260 as compared with the standard sequence of HLA-DQB $1 * 0502$. 
Atacama whose ancestors might have come from the Asian continent carring the aboriginal asian HTLV-I. Further studies on human DNA obtained from other areas should clarify the genetic characteristics of South American ancestors and their relation to specific Asian groups. Thus, more comprehensive and ethnoepidemiologic studies on prehispanic peoples and contemporaries may contribute to breaking new frontiers of anthropology and onco$\operatorname{logy}$ in the history of Mongoloid dispersal from the Asian to the American Continent.

\section{REFERENCES}

AKAZA, T. IMANISHI, T. FUJIWARA, K. et al. HLA 1994 alleles and haplotypes of Japanese population. Major Histocompatibility Gene Complex and Immune Response System (Supplement) 1: 219-226.

ANDRES, D.K., SEABRA, MC., BROWN, M.S. et al.cDNA 1993 cloning of component A of rab geranylgeranyl transferase and demonstration of its role as a rab escort protein. Cell 73, 1091-1099.

BEIN, G. HAASE, D. SCHULT, J. et al. Semiautomated 1994 HLA-DQB 1 typing by fluorescent dye photometry of amplified DNA on microtiter plates. Hum. Immunol. 39:18.

BUNCE, M. O'NEILL, C.U. BARNARDO, M.C.N.0 et al. 1995 Phototyping: comprehensive DNA typing for HLA-A, B, C, DRB I, DRB3, DRB4, DRBS and DQB 1 by PCR with 144 primer mixes utilizing sequence-specific primers (PCR-S SP). Tissue Antigens, 46: 355367.

CANO, R.J. and POINAR, H.N. Rapid isolation of DNA from 1993 fossil and museum specimens suitable for PCR. Bio Techniques, 15: 432-436.

FUJIYAMA, C. FUJIYOSHI, T. MATHUMOTO, D. et al. 1995 Re-evaluation of anti-HTLV-I western blot assay using HTLV-I and HTLVII serum panels. Clin. Diagn. Virol., 4:149-161.

FULLERTON, S.M. HARDING, R.M. BOYCE, TU. and 994 CLEGG, J.B. Molecular and population genetic analysis of allelic sequence diversity at the human beraglobin locus. Proc. Natl. Acad. Sci. USA. 91: 1805-1 809 .

FUJIYOSHI, T. YASHIKI, S. FUJIYAMA, C. et al. Ethnic 1995 segregation of HTLV-I and HTLV-II carriers among South American native Indians. Int. J. Cancer. 63: 510-515

HORAI, S. KONDO, R. SONODA, S. and TAJIMA, K. The 1996 first Americans: different waves of migration to the new world inferred from mitochondria) DNA sequence polymorphisms in Prehistoric Mongoloid Dispersal, eds. T. Akazawa and E.T.E. Szathmary, pp 270-283.

KWOK, S. EHRLICH, G. POIESS, B. et al. Enzymatic 1988 amplification of HTLV-I viral secuences from peripheral blood mononuclear cells and infected tissues. Blood, 72: 1117-1223.
LI, H.C. LOU, H. FUJIYOSHI, T. et al. Ancient HTLV-I 1998 provirus DNA of Andean mummies. (submitted).

MARSH S.G.E. KLA class II region sequences. Tissue 1998 Antigens. 51: 467-507.

MEAD, D.A. PEY, N.K. HERMSTADT, C. et al. A univer1991 sal method for the direct cloning of PCR amplified nucleic acid. Bio/ technology NY. 9: 657-663.

MIURA, T. FUKUNAGA, T. IGARASHI, T. et al. 1994 Phylogenetic subtypes of human Tlymphotropic virus type I and their relations to the anthropological background. Proc. Natl. Acad. Sci. USA. 91: 1124- 1127.

MIURA, T. YAMASHITA, U. VLADIMIR, Z. et al. 1997 Molecular phylogeny of human T-cell leukemia virus type I and II of Amerindians in Colombia and Chile. $\mathbf{J}$. Mol. Evol., 44: S76-82.

SAIKI, R.K. GELFAND, D.H. STOFFEL, S. et al. Primer1988 directed enzymalic amplification of DNA with a thermostable DNA polymerase. Science, 239: 487-491.

SEIKI, M. HATTORI, S. HIRAYAMA, Y. and YOSHIDA, M. 1983 Human adult T-cell leukemia virus: Complete nucleolide sequence of the provirus genome integrated in leukemia cell DNk Proc. Natl. Acad. Sci. USA. 80: 3618-3622

SONODA, S. FUJIYOSHI, T. HTLV-I infection and HLA. 1996 Gann Monogr. Cancer Res., 44: 207218.

TAJIMA, K. and HINUMA, Y. Epidemiology of HTLV-I/II in 1992 Japan and the world. Gann. Monogr. Cancer Res., 39: 129-149.

TAJIMA, K. HTLV-VII related disease with special reference 1996 to is distribution among Mongoloids. Gann Monogr. Cancer Res., 44: 123135.

THOMAS. W.K. and PAABO, S. DNA sequences from old 1993 tissue remains. Methods Enzymol., 224: 406-4 19.

WATANABE, T. SEIKI, M. and YOSHIDA, M. ATLV (Japanese 1994 isolated) and HTLV (USA isolated) are the same strain of retrovirus. Virology. $133,238-241$.

World Health Organization Report on the meeting of a 1990 technical working group on the standardization of western blot assays for HIV-1, HIV-2 and HTLV-I/ HTLV-II. Geneva 23-25 April. 